\title{
New taxa of oribatid mites of the family Liacaridae (Acariformes: Oribatida) from the Caucasus
}

\author{
Umukusum Ya. Shtanchaeva, Luis S. Subías \& Antonio Arillo
}

Shtanchaeva, U. Ya., Subías, L. S. \& Arillo, A. 2009: New taxa of oribatid mites of the family Liacaridae (Acariformes: Oribatida) from the Caucasus. - Entomol. Fennica 20: 245-248.

In this paper new taxa belonging to the family Liacaridae from the Caucasus (Georgia) are described: a new subgenus and species Adoristes (Gordeeviella) krivolutskyi subg. n., sp. n. and a new species Liacarus (Liacarus) longipilis sp. n. The new subgenus Adoristes (Gordeeviella) differs from Adoristes (Adoristes) Hull, 1916 by the shape of its sensilla, with the tip sharply pointed, and of its lamellae, without cuspis. The new species Liacarus (L.) longipilis differs from the rest of species of Liacarus by the presence of very long notogastral setae.

U. Ya. Shtanchaeva, Caspian Institute of Biological Resources, Daghestan Scientific Center, Russian Academy of Sciences, Makhachkala 376000, Russia; Email:umukusum@mail.ru

L. S. Subias \& A. Arillo, Departamento de Zoología y Antropología Física, Facultad de Biología,Universidad Complutense de Madrid, E-28040 Madrid; E-mails: subias@bio.ucm.es; aarillo@teleline.es

Received 7 September 2008, accepted 9 February 2009

\section{Introduction}

Studying some samples of Transcaucasian oribatid mites from Batumi (Georgia), two new species of oribatid mites were discovered, one of them belonging to a new subgenus: Adoristes (Gordeeviella) krivolutskyi subg. n., sp. n. and Liacarus (Liacarus) longipilis sp. n., both described below. With these new findings, 24 species of oribatid mites belonging to the family Liacaridae are known from the Caucasus, belonging to the following genera (and subgenera): Liacarus (Liacarus) Michael, 1898 (11 species), Liacarus (Dorycranosus) Woolley, 1969 (7 species), Adoristes (Adoristes) Hull, 1916 (2 species), Adoristes (Gordeeviella subg. nov.) (1 species) and Birsteinius Krivolutsky, 1965 (3 species) (Shtanchaeva, 2008). Systematic order of the family follows that of Subías (2004).

\section{Taxonomy}

\subsection{Adoristes (Gordeeviella) subg. n.}

Type species. Adoristes (Gordeeviella) krivolutskyi sp. n.

Diagnosis. Sensillus fusiform, distal portion long with the tip sharply pointed. Lamellae virtually without cuspis, without tooth. Lamellar setae inserted on lamellae very close to prodorsal surface. Without translamella. Anterior margin of notogaster slightly concave. Notogaster bearing eleven pairs of short notogastral setae. Epimeral formula $3: 1: 3: 3$. Five pairs of genital setae. Adanal lyrifissures iad situated in paranal position. Tridactylous legs.

Description. Rostrum rounded with a median swelling. Rostral setae smooth. Lamellae long and broad, converging and without translamella; 

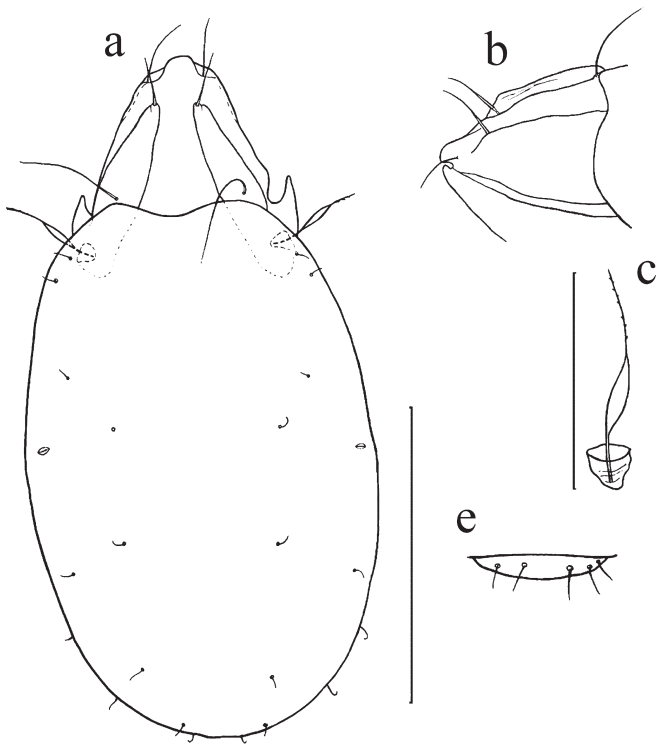

Lamellar cusps barely insinuated and without tooth. Lamellar setae are slightly stronger than rostral setae reaching rostral margin and inserted in the distal edge of the lamellae, almost over the prodorsal surface. Interlamellar setae are smooth and almost as long as lamellae. Bothridium hidden by the anterior margin of the notogaster. Sensillus shaped as is usual within the genus with its head fusiform and smooth with a length similar to that of tail and with a long distal portion sharply pointed and slightly barbed. Notogaster elliptical and elongated, with its anterior margin concave, bearing eleven pairs of short, thin and smooth setae. Lyrifissures im very short. Epimeres II and III are parallel and sternal apodeme is not developed. Epimeral formula 3:1:3:3. Five pairs of genital setae, one pair of aggenital setae, two pairs of anal setae and three pairs of long adanal setae. Adanal lyrifissures iad are short, situated in paranal position close to the lateral margins of anal plates. Tridactylous legs.

Discussion. The new subgenus Adoristes (Gordeeviella) differs from Adoristes (Adoristes) Hull, 1916 by the shape of its sensilla, quite different with the tip sharply pointed, and of its lamellae, without cuspis. Because the shape of the sensillla Adoristes (Gordeeviella) has some similarities with the subgenus Liacarus (Liacarus) Michael, 1898, but differs from it by the shape of the lamellae, never fused or with trans-

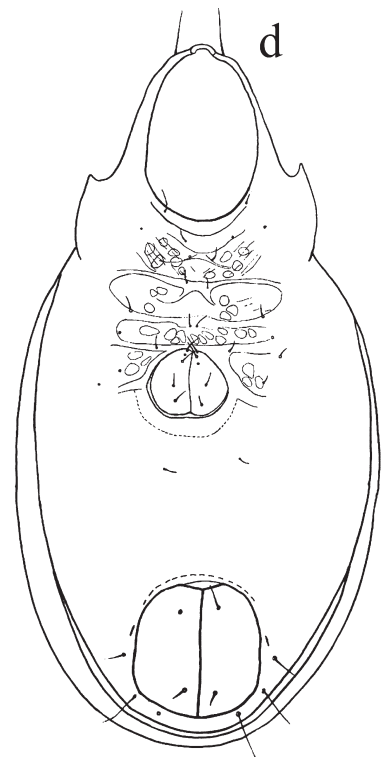

Fig. 1. Adoristes (Gordeeviella) krivolutskyi subg. n., sp. n. (holotype). - a. Dorsal view. - b. Lateral view of prodorsum. - c. Sensillus. - d. Ventral view. - e. Lateral view of genital plates. Scale bar $150 \mu \mathrm{m}$ (except in $c$ and e $100 \mu \mathrm{m})$.

lamella, by the presence of five pairs of genital setae and by the paranal position of lyrifissures iad. The new subgenus has also some similarities with the genus Planoristes, described by Iturrondobeitia and Subías (1978) from northern Spain. The only species included in Planoristes lacks lamellar cuspis and translamella, like Adoristes (Gordeeviella), with the lamellar seta inserted on the prodorsal surface. But the sensillus of Planoristes is quite different, without the distally sharp tip, and Planoristes has four pairs of genital setae and monodactylous legs.

Etymology. Named after our colleague, acarologist Elena W. Gordeeva (Karadag Natural Reserve of the National Academy of Sciences of Ukraine).

\subsection{Adoristes (Gordeeviella) krivolutskyi sp. n. (Fig. 1)}

Material. All the material sampled at the Botanical Gardens in Batumi (Georgia) (D. A. Krivolutsky leg., 1973): soil under Eucalyptus (holotype and 12 paratypes), soil under conifers (2 paratypes), relict forest of conifers ( 9 paratypes). Holotype (female) and paratypes deposited in the collection of the Complutense University (Madrid, Spain).

Diagnosis. As for the subgenus. 
Fig. 2. Liacarus

(Liacarus) longipilis sp. n. - a. Dorsal view (holotype). - b. Prodorsum (paratype). - c. Posterior notogastral setae of the holotype and the paratype. $-d$. Ventral view (holotype). Scale bar 200 $\mu \mathrm{m}$ (a and d), $80 \mu \mathrm{m}$ (b) and $150 \mu \mathrm{m}$ (c).
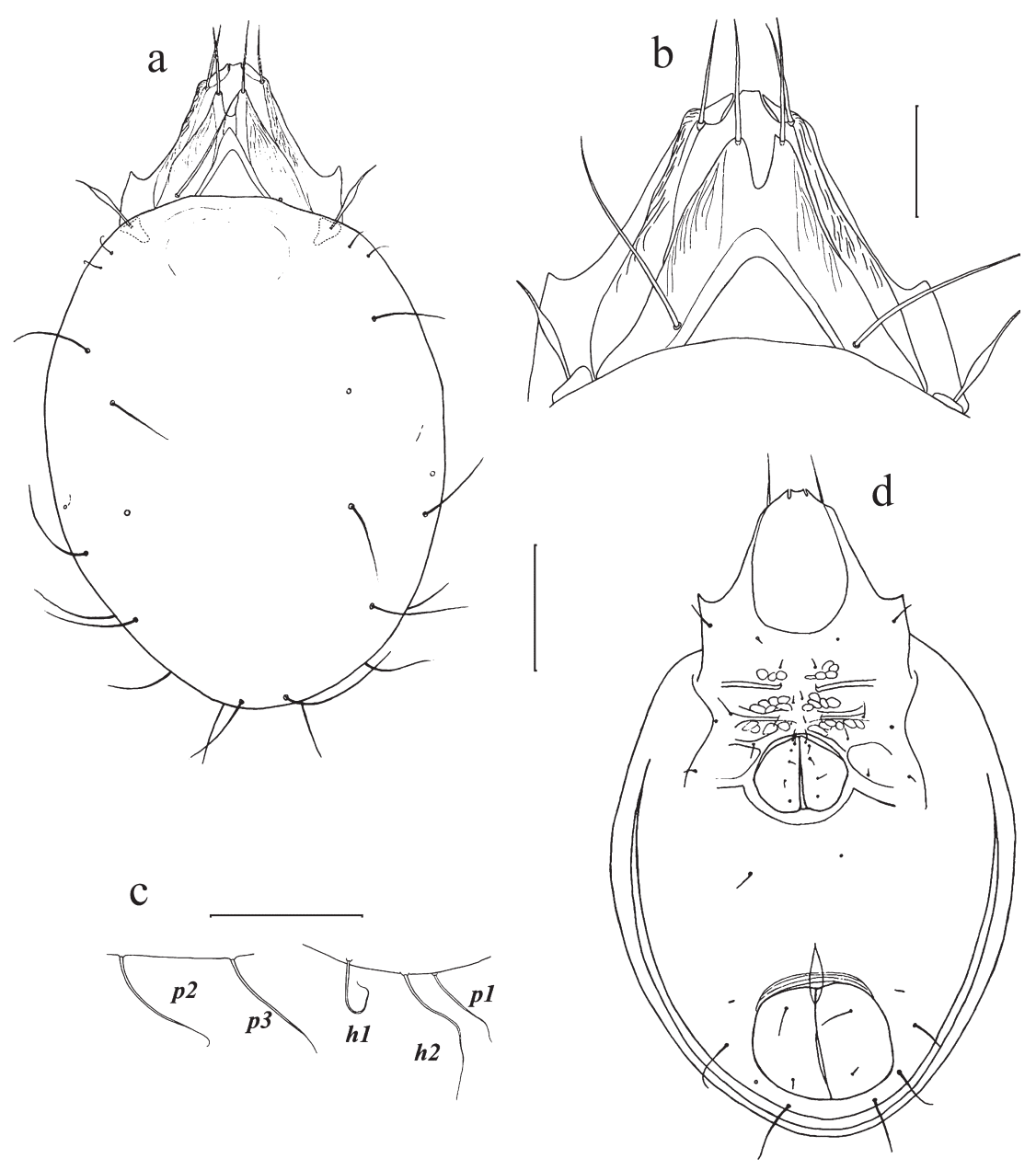

Description. Measurements: 500-640 $\mu \mathrm{m}$ long and 250-330 $\mu \mathrm{m}$ wide. Integument brown, rather dark.

Prodorsum (Fig. 1a). Rostrum rounded with median swelling. Rostral setae $(45-63 \mu \mathrm{m})$ smooth. Lamellae (Fig. 1b) long and broad, without translamella and lamellar cuspids barely insinuated. Smooth lamellar setae $(50-53 \mu \mathrm{m})$ are slightly stronger than rostral setae reaching rostral margin and inserted on distal edge of lamellae, almost over prodorsal surface. Interlamellar setae smooth and long (180-195 $\mu \mathrm{m})$. Bothridium hidden by anterior margin of notogaster. Sensillus $(88-100 \mu \mathrm{m})$ shaped as usual within the subgenus Liacarus (Liacarus) (Fig. 1c), with head fusiform and smooth with length similar to that of tail $(25-35 \mu \mathrm{m})$ and with long distal portion sharply pointed and slightly barbed
(35-45 $\mu \mathrm{m})$. Tutorium being long and narrow, best viewed in lateral orientation (Fig. 1b).

Notogaster (Fig. 1a) elongated, elliptical and somewhat flattened. Anterior margin quite concave. Eleven pairs of very short $(10 \mu \mathrm{m})$ smooth and thin notogastral setae. Lyrifissures im very short $(5 \mu \mathrm{m})$ and difficult to see.

Ventral region (Fig. 1d). Epimeral region reticulated due to muscle insertions. Epimeres II and III parallel and sternal apodeme not developed. Epimeral setae short $(10-13 \mu \mathrm{m})$ smooth and thin. Epimeral formula 3:1:3:3. Genital opening approximately $50 \times 65 \mu \mathrm{m}$ while anal opening almost twice as big. Five pairs of genital setae, three anterior pairs $(13 \mu \mathrm{m})$ very close to each other and longer than posterior two pairs $(9 \mu \mathrm{m})$ (Fig. 1e). One pair of agenital setae $(10 \mu \mathrm{m})$, two pairs of anal setae $(12-14 \mu \mathrm{m})$ and three pairs of 
adanal setae (18-38 $\mu \mathrm{m})$. Adanal lyrifissures iad short situated in paranal position close to lateral margins of anal plates. Legs tridactylous.

Etymology. Named after renowned Russian acarologist the late D. A. Krivolutsky.

Remarks. The new species is the only included in the new subgenus and differs from all others of the genus Adoristes Hull, 1916, because of the already mentioned subgeneric characters.

\subsection{Liacarus (Liacarus) longipilis sp. $\mathrm{n}$. (Fig. 2)}

Material. All the material sampled at the Botanical Gardens in Batumi (Georgia) (D. A. Krivolutsky leg., 1973): soil under Eucalyptus (holotype) and soil under conifers (paratype). Holotype (female) and paratype deposited in the collection of the Complutense University (Madrid, Spain).

Diagnosis. The new species differs from other species of Liacarus by the presence of very long notogastral setae.

Description. Measurements: 920-1,050 $\mu \mathrm{m}$ long and 600-630 $\mu \mathrm{m}$ wide. Integument dark brown.

Prodorsum (Fig. 2a). Length about $230 \mu \mathrm{m}$. Rostrum rounded with median swelling. Rostral setae $(75-90 \mu \mathrm{m})$ smooth and inserted at end of long and rugose tutorium (visible dorsally). Broad and long lamellae with striate external margin, fused at $55 \mu \mathrm{m}$ from notogastral margin. Well developed cuspis $(35 \mu \mathrm{m})$ without tooth (holotype) or with a vestigial one on inner margin (paratype) (Fig. 2b). Lamellar setae (110-120 $\mu \mathrm{m})$ smooth, stronger than rostral setae, inserted on the distal edge of lamellar cuspis and surpassing rostral margin more than half of its length. Interlamellar setae smooth (except tip slightly barbed) thin and longer than rest of prodorsal setae $(200-210 \mu \mathrm{m})$, inserted on basal part of lamellae. Bothridium hidden by anterior margin of notogaster. Sensillus (125-135 $\mu \mathrm{m})$ shaped as usual within the genus Liacarus with head fusiform and smooth with length $(45 \mu \mathrm{m})$ similar to that of tail $(40-55 \mu \mathrm{m})$, distal portion sharply pointed, shorter $(35-40 \mu \mathrm{m})$ and slightly barbed.

Broad and elliptical notogaster $(475 \mu \mathrm{m})$ with anterior margin slightly convex. Eleven pairs of notogastral setae present, pairs $c_{2}$ and $c_{3}$ very thin and short $(35-40 \mu \mathrm{m})$ as is usual among species of Liacarus, other notogastral setae longer, smooth and sometimes with their tip curved: $l a-$ $135 \mu \mathrm{m}, l m-90 \mu \mathrm{m}, l p-100 \mu \mathrm{m}, h_{l}-135-140$ $\mu \mathrm{m}, h_{2}-135-150 \mu \mathrm{m}, h_{3}-150-160 \mu \mathrm{m}, p_{1}-90$ $100 \mu \mathrm{m}, p_{2}-140 \mu \mathrm{m}, p_{3}-125-130 \mu \mathrm{m}$; some setae from series $h$ and $p$ of paratype with flagelliform tip (Fig. 2c). Lyrifissures $i m$ very short and barely visible, as associated glands.

Ventral side (Fig. 2d). Epimeral region reticulated due to muscular insertions. Epimeres II and III parallel without developed sternal apodeme. Epimeral setae with diverse length $(15-35 \mu \mathrm{m})$. Epimeral formula 3:1:3:3. Genital $(125 \times 150 \mu \mathrm{m})$ and anal $(195 \times 220 \mu \mathrm{m})$ openings wider than longer. Six pairs of very short and thin genital setae (20-26 $\mu \mathrm{m})$, anterior pairs very close to each other. One pair of aggenital setae $-35 \mu \mathrm{m}, 2$ pairs of anal setae $-55-60 \mu \mathrm{m}$ and 3 pairs of adanal setae $-65-90 \mu \mathrm{m}$. Lyrifissures iad very short $(10-15 \mu \mathrm{m})$ situated at level of anterior margin of anal plates but far from them. Legs tridactylous.

Etymology. longipilis refers to the long notogastral setae.

Remarks. Because of the length of the notogastral setae, this species has some similarities with those of Birsteinius, but this genus differs by the shape of sensillus, without the tip sharply pointed, and by the 5 pairs of genital setae.

Acknowledgements. This paper is dedicated to the late Dr. Krivolutsky who made these samples available. We are grateful to Ms. Joann Wilson for improving the English of the manuscript. This study was possible thanks to the financial economic support of the presidency of the Russian Academy of Sciences through its program "Biodiversity" and the project (Proyecto SAB2005-0021) of the Complutense University of Madrid.

\section{References}

Iturrondobeitia, J. C. \& Subías, L. S. 1978: Contribución al conocimiento de los oribátidos (Acarida, Oribatida) del País Vasco, II. - Boletín de la Asociación Española de Entomología 2: 87-90.

Shtanchaeva, U. Ya., 2008: A review of oribatid mites of the family Liacaridae (Acariformes, Oribatida) from the Caucasus. - Entomological Review 88: 244-257.

Subías L.S., 2004: Listado sistemático, sinonímico y biogeográfico de los acaros oribátidos (Acariformes, Oribatida) del mundo (1758-2002) — Graellsia 60: 3305. 